\title{
Reduction of environmental impact of solid domestic landfills of residential area due to their recycling
}

\author{
Tatiana Zhilina ${ }^{1,{ }^{*}, \text { Konstantin Afonin }^{1} \text {, and Alla Zagorskaya }}{ }^{1}$ \\ ${ }^{1}$ Tyumen Industrial University, Volodarskogo str., 38, Tyumen, 625000, Russia
}

\begin{abstract}
In the research it was considered dynamics of growth of municipal solid waste landfill in a city of Tyumen for six years Shows the distribution of waste by placing objects, calculated amounts of solid household and industrial wastes placed on landfill south of the Tyumen region. Comparison of components suitable for generating methane for household waste and scum of wastewater. Formation of methane and carbon dioxide at various stages of fermentation of municipal solid waste. Specific generation of municipal waste per 1 inhabitant is calculated. The concept of co-utilization of municipal waste of apartment buildings. Comparative estimate of various options for fermentation of waste. It is established that the amount of methane produced is sufficient to compensate for the communal needs of apartment buildings. Reducing the anthropogenic burden on landfill is possible upon conditions of the implementation of biogas recovery and its reuse on the site of waste generation that is conducive to development of productions based on using secondary energy resources on the cheap raw materials basis.
\end{abstract}

\section{Introduction}

Tyumen region is intensive development area. According to [1] the average population growth per year in the territory of Tyumen region over the past 5 years amounted to $1.1 \%$.Industrial growth averaged $5.6 \%$. All this leads to intensification of the growth of production and consumption wastes. The planned increase in the amount of waste generated in the Tyumen region is expected to be under $10 \%$ annually, but in practice it is $18-20 \%$ annually [2].

${ }^{*}$ Corresponding author: ts-z@yandex.ru 
Municipal solid and industrial wastes placed on landfill south of the Tyumen region, presented in Figure 1.

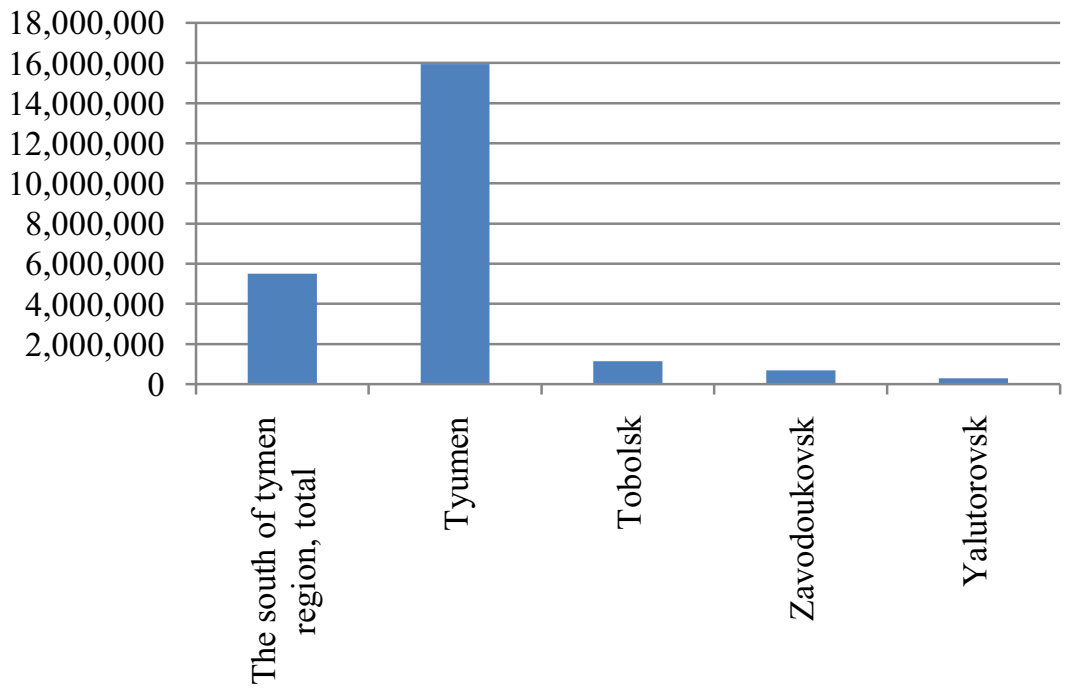

Fig.1.The total amount of solid industrial and household waste produced on the territory of Tyumen region, in $\mathrm{m}^{3} /$ year.

Approximately 1378.3 thousand tons per year of solid municipal waste and close to them on the composition placed on landfill of solid municipal wastes or landfills [2], which is $47.7 \%$ of total waste generated.

According to [2] to the south of Tyumen region at the beginning of the 2015 year was 667 objects properties of solid municipal waste. Allocation of waste among waste disposal sites is shown in the Figure 2.

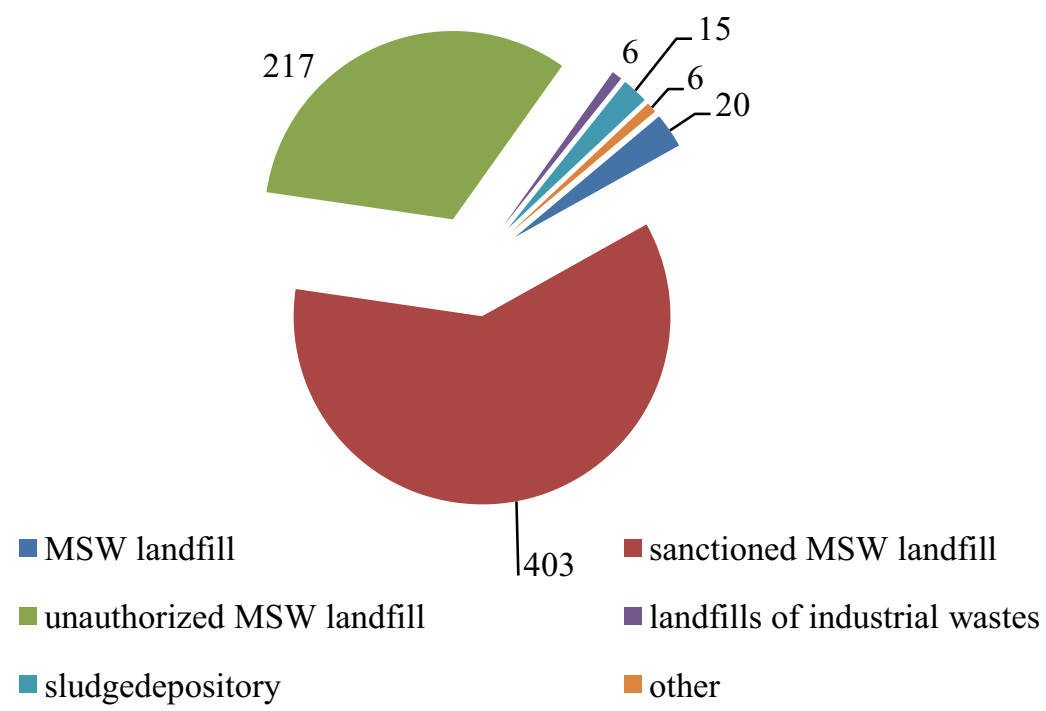

Fig.2.The number of objects placing waste on the territory south of the Tyumen region. 
The total area of land registered polygons and landfills in the region is approximately 1146.34 hectares, including 201 hectares in the city of Tyumen.
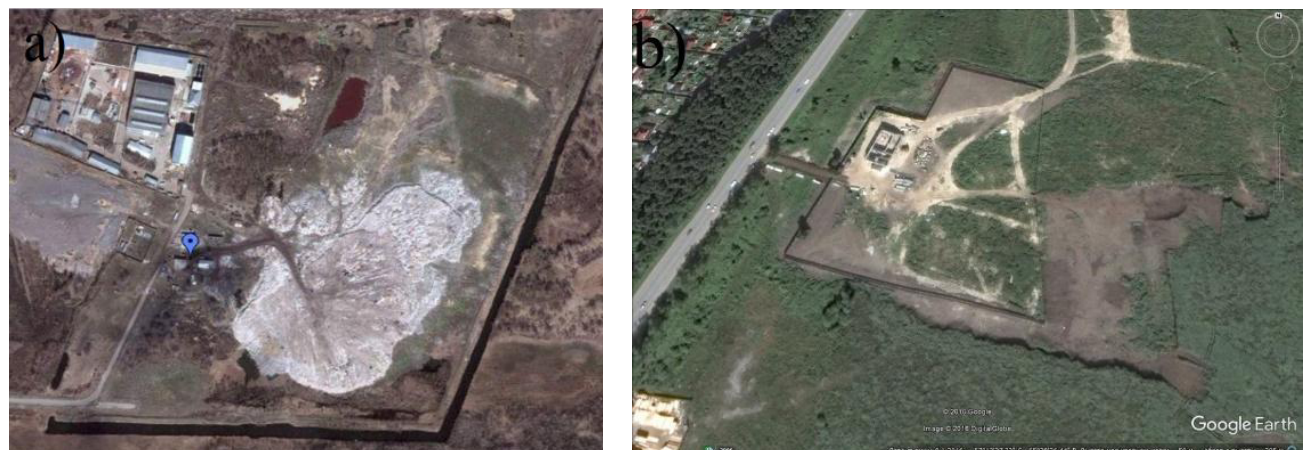

Fig.3. Territory of Velizhanskiy solid waste landfill according to GoogleEarthPro(A- 2016 year, august; Б - 2010 year, august)

Given the dynamics of formation of wastes of production and consumption, the amount of waste and therefore the territory earmarked for their properties, will only increase.

It should be remembered that solid waste landfills are intense source of environmental pollution [4].

Under clause 5.16[8] the use of the territory after the reclamation landfill under construction is not allowed and means of waste disposal grounds affect land use conditions even after closing.

On the territory of Tyumen region, there are 26 industrial enterprises and industrial associations, utilizing the waste industry and agriculture.

However, for solid household waste and close to them according to their composition, modern processing technologies aimed at the recovery of secondary energy and material resources. Partly the huge territory of the region, as well as the richness and diversity of hydrocarbon resources produced in the region facilitate this.

It must be stressed that municipal solid waste has a huge value. According to the administrations of municipal and city districts, waste sorting for recovery from secondary raw materials from municipal solid waste is not carried out. According to various estimates they contain from $70 \%$ to $80 \%$ recyclable materials (paper, wood, plastic, metal, etc.) [2].

\section{Materials and Methods}

Increasing resource potential of waste can contribute to the accumulation of waste separately, centralized and local sorting, use of modern methods of transportation and utilization of solid household waste.

Move to rational waste management policy will lead to the improvement of the ecological situation in the Tyumen region, as well as will contribute to the creation of a fundamentally new "green" economy.

The task of the research included: define specific yield of biogas and its characteristics at the co-digestion of waste accumulated in apartment buildings and waste extracted from municipal sewage water. And also the conditions for optimizing methane production.

As the object of the study were selected municipal solid waste generated in the residential area of the city of Tyumen, and the sludge of domestic wastewater. The average amount of waste, calculated on the basis of norms of accumulation of solid waste from the population, approved by local authorities [5].Composition of municipal solid waste (MSW) is defined according to[4]. 
The ratio of components is suitable for the generation of methane is shown in Figure 4.

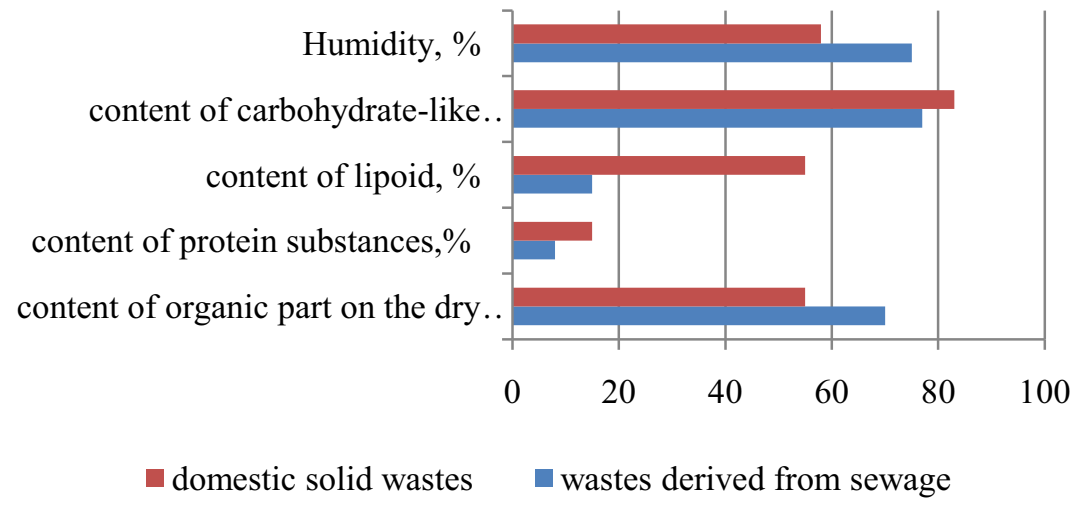

Fig.4. Content of recyclable components in wastes of apartment houses, \%.

According to the presented scheme, methanogenesis is carried out in underground reactors with gradually-applied loading directly at the place of waste generation.

The degradation of organic fraction of solid waste in the reactor takes place in five consecutive stages:

- Phase I - Initial adjustment (aerobic bacterial decomposition);

- Phase II - Transition phase (anaerobic decomposition, but still without methane formation - acid fermentation);

- Phase III - Acid phase (anaerobic decomposition with inconsistent release of methane mixed fermentation);

- Phase IV - Methane fermentation phase (anaerobic decomposition with consistent methane formation);

- Phase V - Maturation phase (anaerobic attenuation).

- Mechanism of methanogenesis chemistry can be described by following chemical reactions:

- Fermentation of organic acids during 3-d phase:

$$
\begin{gathered}
4 \mathrm{H}-\mathrm{COOH}=\mathrm{CH}_{4}+3 \mathrm{CO}_{2}+2 \mathrm{H}_{2} \mathrm{O} \\
\mathrm{CH}_{3}-\mathrm{COOH}=\mathrm{CH}_{4}+\mathrm{CO}_{2} \\
4 \mathrm{CH}_{3}-\mathrm{OH}=3 \mathrm{CH}_{4}+\mathrm{CO}_{2}+2 \mathrm{H}_{2} \mathrm{O} \\
2 \mathrm{CH}_{3}-\mathrm{CH}_{2}-\mathrm{OH}+\mathrm{CO}_{2}=\mathrm{CH}_{4}+2 \mathrm{CH}_{3} \mathrm{COOH}
\end{gathered}
$$

- Recoveryofcarbonoxides in the step of constant release of methane:

$$
\begin{gathered}
\mathrm{CO}_{2}+4 \mathrm{H}_{2}=\mathrm{CH}_{4}+2 \mathrm{H}_{2} \mathrm{O} ; \\
4 \mathrm{CO}+2 \mathrm{H}_{2} \mathrm{O}=\mathrm{CH}_{4}+3 \mathrm{CO}_{2} .
\end{gathered}
$$

According to studies, the generation of methane and carbon dioxide when disposing of pre-shredded solid municipal waste at different stages of fermentation was within $88 \mathrm{~kg} / \mathrm{t}$, methane and $115 \mathrm{~kg} / \mathrm{t}$ of $\mathrm{CO}_{2}$. The results presented in Figure 5.

Therefore, it is advisable to use reusable fractions of wastewater wastes to increase the rate of methane formation. The degree of waste generation is determined in accordance 
with the state code(in Russia) relating to sewerage systems [5], and for apartment buildings from 1.5 to 25 liters per day per capita.

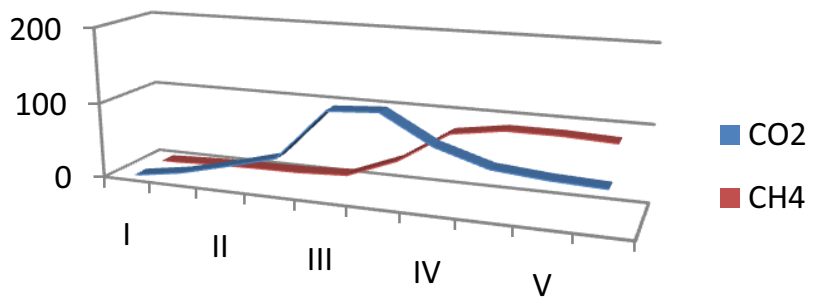

Fig.5.Formation of methane and carbon dioxide at various stages of fermentation of municipal solid waste in $\mathrm{kg} / \mathrm{t}$.

The benefits of using the co-recycling of MSW and sludge sewage water for methane production is confirmed a by ration (Figure 6) of amount of solid waste and sludge per capita.

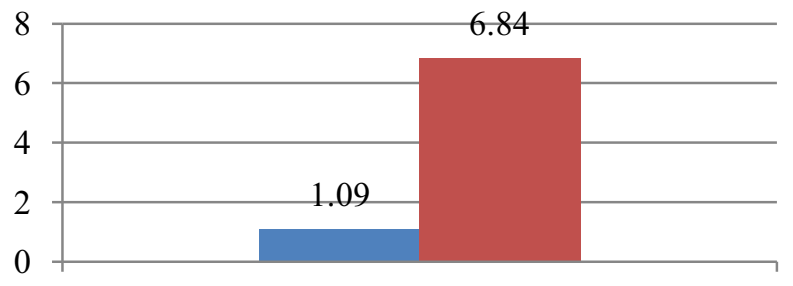

tons per year

amount of wastes per one capita

amount of wastes derived from sewage per one capita

Fig. 6. Specific formation of municipal waste and sewage sludge per 1 inhabitant in tons per year.

Decentralized scheme as version of co-utilization has been discussed (Figure 7).

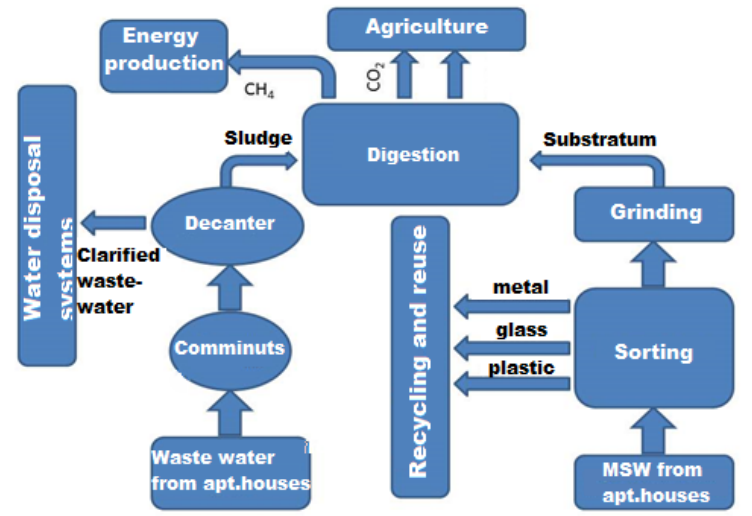

Fig. 7. The concept of joint recycling (digestion) of municipal wastes of apartment buildings. 
According to the presented scheme, methanogenesis is carried out in underground reactors with gradually-applied loading directly at the place of waste generation.

Considered the scheme of the municipal waste disposal also offers sludge extraction from sewage water from these fractions. Large water-waste with fractional composition of more than $16 \mathrm{~mm}$ create conditions for stoppage networks, prevent proper ventilation, which generally degrades the health and condition of in-building drainage networks. The scheme involves the use of modern equipment (decanters and lattice-crusher) for extraction and crushing of waste in sewage water. The equipment allows to disperse sludge to $75 \%$. Clarified sewage are being returned to the domestic sewerage system for further treatment and disposal in urban wastewater treatment plants. Specific yield biogas during the methane fermentation of mixture of crushed waste and sewage sludge was determined by the equation [7]:

$$
Q w=10^{-6} R(100-W)(0,92 L+0,62 C+0,34 P),
$$

Where:Q - specific yield of biogas for the period of its active generation, $\mathrm{kg} / \mathrm{kg}$ of waste; $\mathrm{R}$ - content of organic components in the waste, $\% ; \mathrm{F}$ - content of fat-like substances in the waste organics, $\% ; \mathrm{H}$ - content of carbohydrates in the waste organics, $\% ; \mathrm{P}$ - content of protein substances in the waste organics, $\%, \mathrm{~W}-$ actual moisture of waste mixture determined via analysis of waste samples, $\%$.

Quantitative yield of biogas per year, referred to one ton of waste, defined by the formula:

$$
P=\frac{Q w}{t_{f e r m}} \cdot 10^{3} \mathrm{~kg} / \mathrm{t}
$$

Where, $t_{\text {ferm }}$-period of full fermentation of organic part of wastes, in years.

The methodology for determining the quality and quantity of biogas was chosen [4]. Brief description of the generated biogas was determined in a study referred with issues concerning with landfills gas emissions [3] and is shown in Figure 8.

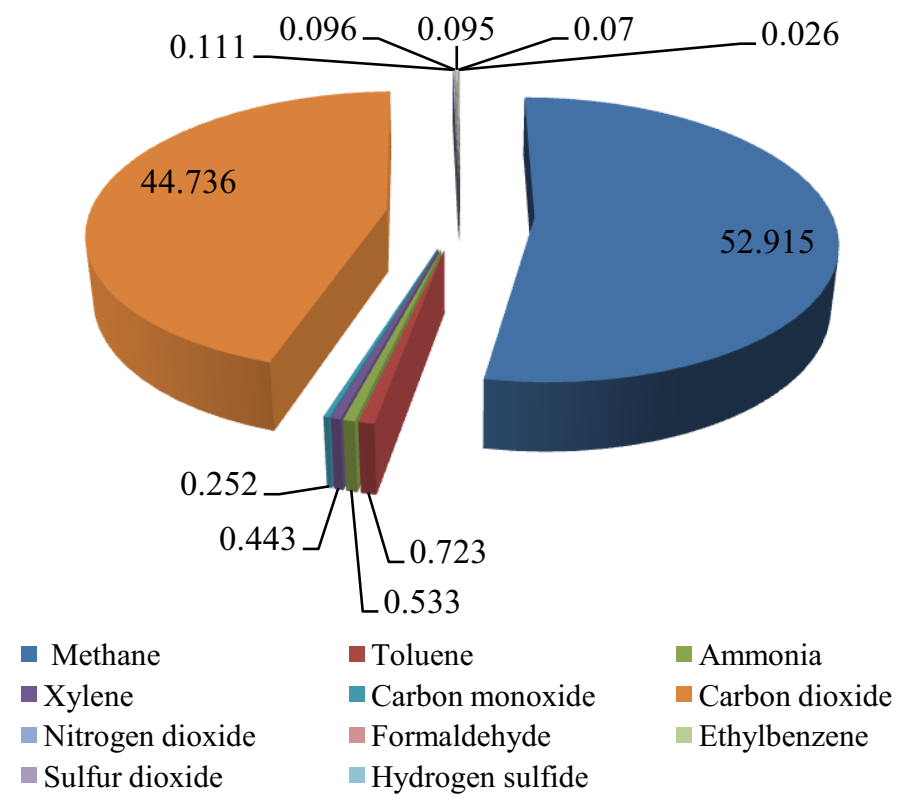

Fig. 8.Ingredient composition of biogas during the path of constant generation (the pathe IV of methanogenesis). 
A comparative assessment of various options for fermentation of waste has shown that the combined fermentation of waste of domestic wastewater and solid domestic waste reduces the specific yield of methane, due to the high residual moisture of the dehydrated sediments.The increase in methane emissions occur only by increasing the mass of the substrate. The results shown in Figure 9.

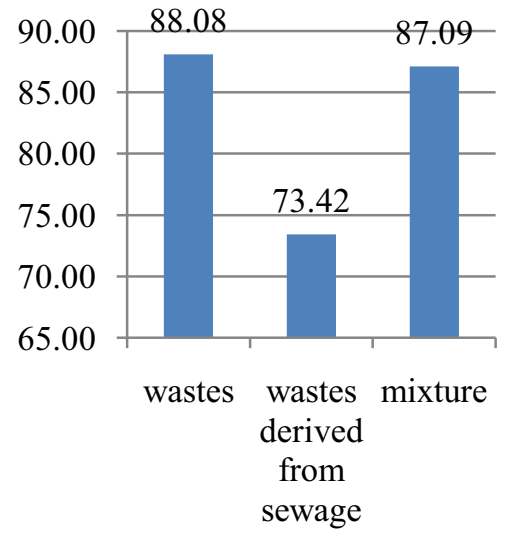

- specific methane yield

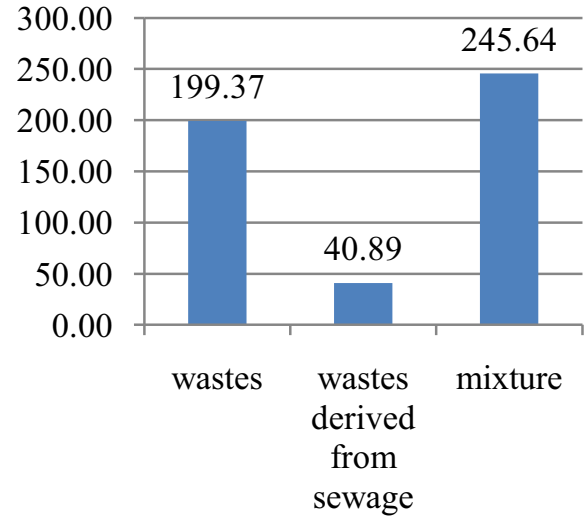

total amount of methane

Fig. 9. Specific and total yield of methane during separated and co-digestion of wastes of apartment houses, $\mathrm{kg} / \mathrm{t}$.

\section{Results}

To suppress residual moisture disposal household sewage, it is possible to use neutral chemical means that do not affect the chemical composition and $\mathrm{pH}$ of the substrate, reducing humidity waste with $75 \%$ to $68 \%$.As additives have been selected the most accessible and widely used in the remediation of Oasis Foam and artificial zeolite NaAIn comparison, several options have considered the substrate without making dehumidifiers. The results shown in Table 1.

Table 1.The amount of products formed in the co-digestion of waste.

\begin{tabular}{|c|c|c|c|c|}
\hline \multirow[b]{2}{*}{$\begin{array}{c}\text { Specific } \\
\text { yield of } \\
\text { products of } \\
\text { fermentation, } \\
\mathrm{kg} / \mathrm{t}\end{array}$} & \multicolumn{4}{|c|}{ Content of substrate in $\%$ to total mass } \\
\hline & $\begin{array}{c}\text { SDW } \\
(100 \%) \\
\text { Humidity } \\
58 \%\end{array}$ & $\begin{array}{c}\text { SDW }(20 \%), \\
\text { Waste derived } \\
\text { from sewage } \\
(80 \%) \\
\text { Humidity } 71,6 \%\end{array}$ & $\begin{array}{c}\text { SDW (20\%), } \\
\text { Waste derived } \\
\text { from sewage } \\
(75 \%) \\
\text { OasisFoam }(5 \%) \\
\text { Humidity } \\
67,85 \% \\
\end{array}$ & $\begin{array}{c}\text { SDW }(20 \%) \text {, Waste } \\
\text { derived from sewage } \\
(75 \%) \\
\text { Zeolite }(5 \%) \\
\text { Humidity } 67,85 \%\end{array}$ \\
\hline Methane & 88.0 & 132.0 & 93.9 & 117.3 \\
\hline $\begin{array}{l}\text { Carbon } \\
\text { dioxide }\end{array}$ & 117.3 & 117.3 & 132.0 & 111.5 \\
\hline Humus & 88.0 & 44.0 & 67.5 & 64.5 \\
\hline
\end{tabular}

The study made it possible to establish that the use of sorbents-desiccants intensifies the processes of methanogenesis, increasing the yield of methane by approximately 1.3 times. However, it should be noted that the amount of humus-like product decreases with use of ameliorants. In considering, the resource aspects derived from the fermentation products 
(methane, carbon dioxide and soil), it should note that all of them could be used to formation place.

Specific calorific value and energy value of the resulting biogas is comparable to physical-chemical characteristics of natural gas, which enables the use of biogas for local boiler and roof. The amount of produced biogas can compensate for the heat loss for hot water preparation.

Produced as a result of fermentation the carbon dioxide can be used to accelerate plant growth on the quarter and adjacent territories, ensure the fertilization of small landscape forms and vertical gardening. The amount of carbon dioxide produced is enough to ensure the daily need for $106 \mathrm{~m}^{2}$ plants [7].

The amount of humus-like product (humic substance) formed as a residue from the fermentation depends on the composition of waste and bio-methanogenesis conditions. Coprocessing of municipal solid waste and sewage of houses contribute to humus production in the average volume of $1.64 \mathrm{t} /$ year per 1 inhabitant. The resulting product of anaerobic digestion - humic product - can be used for soil remediation in the technogenic contaminated territories as well as for land reclamation, and as soil for planting

\section{Conclusion}

The accumulation of waste in the environment radically affects all the elements of the biosphere: changing topography, evaporation of moisture, ground water regime, the nature of the vegetation, the modes of surface runoff, accumulation of toxic products in a biota and transfer through the food chain. Storage of waste associated with the disposal of large areas, often uninsurable restoration and rehabilitation after the end of life [7]. The total impact of waste inflicts significant ecological and economic damage.

Processing of municipal solid waste by anaerobic digestion reduces the burden on landfill, which will lead to positive changes in the biosphere as a whole.

Co-processing of municipal waste at the place of formation improves hydraulic modes and operating conditions of drainage networks by extraction of large floating impurities (scum).

Added to this is the fact that it bio-methanogenesis generate products suitable for use in the national economy, as a source of thermal, mechanical and electrical energy, the catalyst of growth of plants or soils.

Total rejection of solid municipal wastes storage and moving to their anaerobic process reduce area placements of waste at $90-95 \%$.

\section{References}

1. Tyumen region in figures(Tyumen region Agency of Federal State Statistics Service, Tyumen, 2015)

2. Regional waste inventory of Tyumen region(Tyumen, 2015)

3. Report about ecology of Tyumen region in 2014 year(Government of Tyumen region, Tyumen, 2015)

4. K.V.Afonin, T.S.Zhilina, A.A. Zagorskaya, Fundamentalresearch11, 987-990 (2014)

5. Instructional guidelines for calculation of quantitative characteristics of air pollutant emissions from solid domestic landfills and industrial wastes (Moscow, 1995)

6. Russian Standard SanRaN 32.13330.2012, SNiP 2.04.03-85

7. V.V. Blagutina, Chemistry and life 1, 36-39(2007)

8. Russian Standard SanRaN 2.1.7.1038-01 